

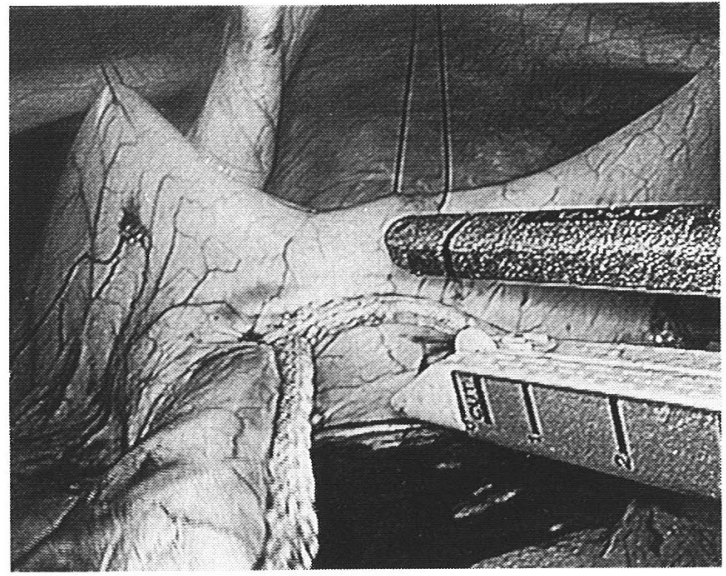

図 1 内視鏡下に胃壁全層付き大網を採取。 胃壁の切除は endo-stapler 使用。

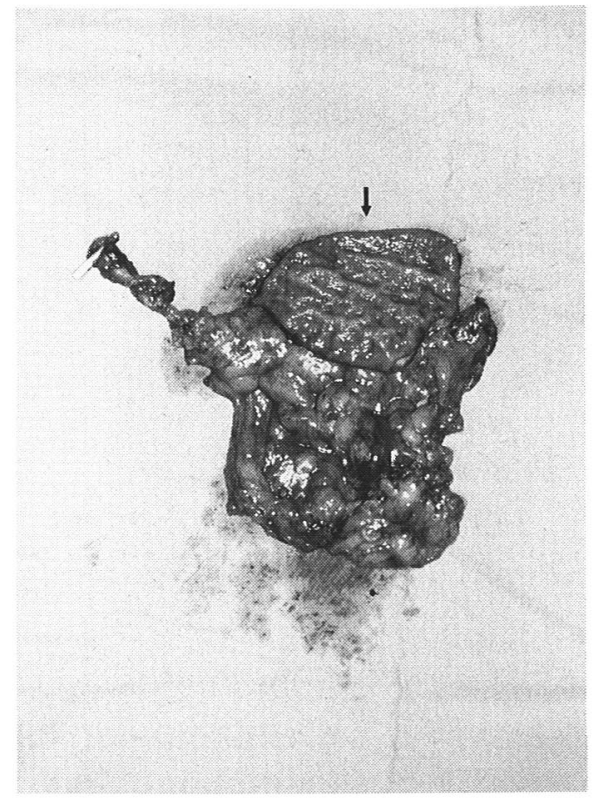

図 2 採取した胃壁全層付き大網。 矢印は胃壁 (全層)。

たが部分壊死が生じ，眼窩内壁から眼窩床の欠損ができ 鼻腔との交通が生じた（図 5)。放射線治療を受けて拧 り感染もあったため，胃漿膜筋層付き大網による充填を 行った。本症例では, 内視鏡補助下最小開腹術にて胃漿 膜筋層付き大網を採取した（図 6)。挙上した胃漿膜筋 層を眼窩内壁から眼窩床に patchすることで鼻腔との 交通を遮断し（図 7 (a)), 眼窝内を大網で充填した。 充填した大網上には網状植皮を行った。また，㚘骨弓上 方の陥凹部にも大網を充填した。右胃大網動静脈は顔面

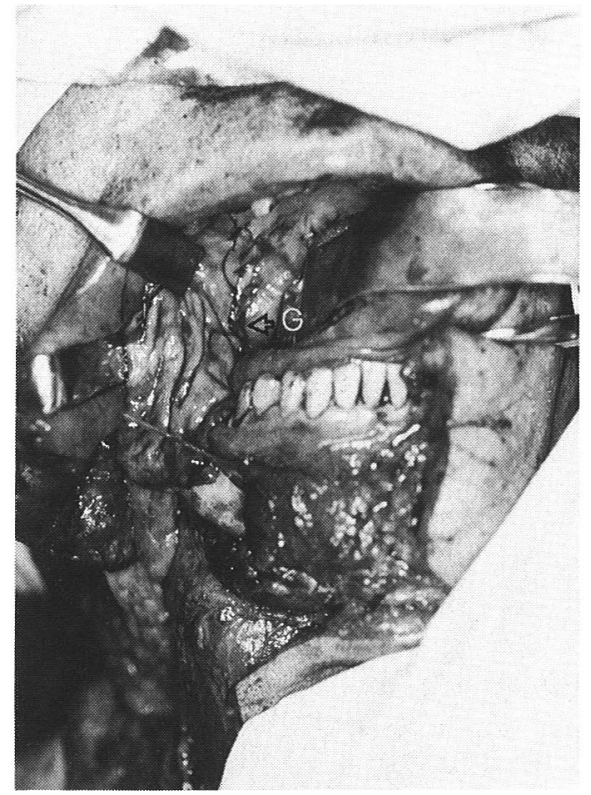

図 3 煩粘膜欠損部に胃壁を縫合。( G：胃壁)

動静脈に端々吻合した（図７（b）。術後経過は良好で あった（図 8)。

【症例 4】58 歳女性。脳腫瘍切除後の䯣液瘦に対し硬 膜の補強に胃漿膜筋層の patch を行い, その上を大網 にて cover した。一部皮膚欠損が生じたため, 大網上 に網状植皮を行った。右胃大網動静脈は顔面動静脈と端々 吻合した。術後経過は良好であった。 


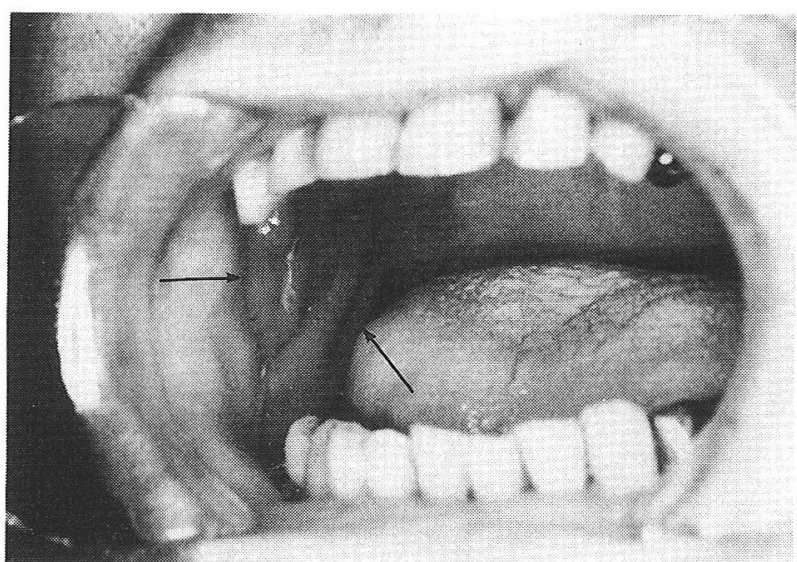

図 4 術後 6 ケ月。矢印は胃壁。

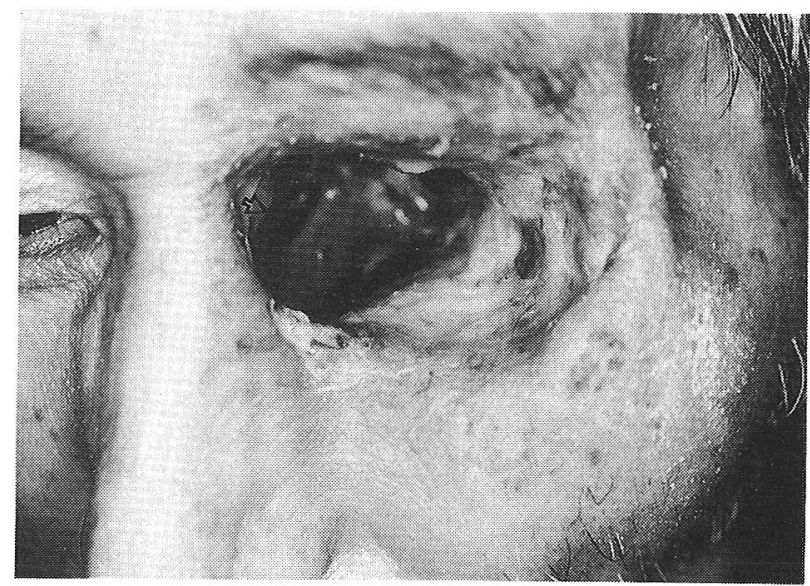

図 5 術前の状態。矢印は鼻腔との交通部。

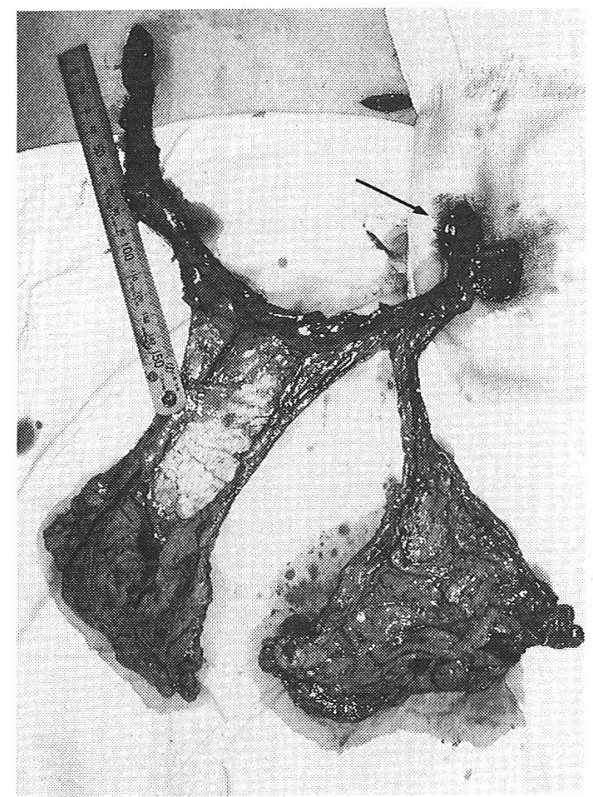

考察

胃壁付き大網弁は，1977 年に Parachristou $ら^{3)}$ が最 初に報告したもので, 右胃大網動静脈からの胃壁枝を利 用した胃の大弯側の一部を全層で挙上して大網との連合 皮弁として利用するものである。また，胃漿膜筋層付き 大網弁はわれわれが考案した ると手術手技はやや難しいが粘液の分泌がないこと， water-tight や air-tight が得られることなど有用であ る。採取できる胃壁の大きさは 1 本の胃壁枝で $5 \times 10$ $\mathrm{cm}$ まで採取できる。

胃壁全層を口腔内に用いる場合, 胃酸の分泌が問題と なるが，制酸剤の投与によりコントロールできる。症例 2 においては, 舌が動かないためびらんを繰り返してい るが, 舌の動きがよくて燕下が可能であれば症例 1 と同

一図 6 内視鏡補助下最小開腹術にて胃漿膜筋層付き大網を 採取。矢印は胃壁 (漿膜筋層)。 

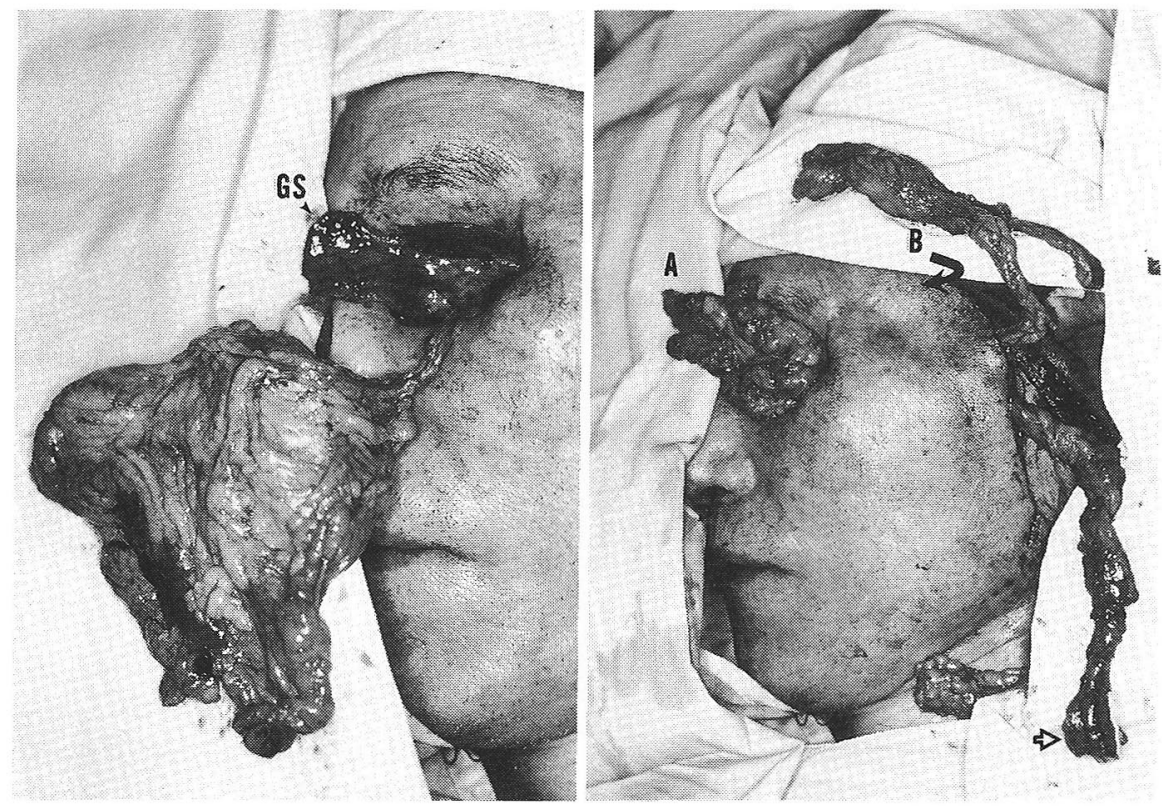

図 7 （a）胃壁を眼窩内壁から眼窩床に固定。 GS：胃壁（漿膜筋層）

(b) 眼窩内 (A) および頬骨弓上方の陥凹部 (B) に大網を充填。白抜き矢印は右胃大網動静脈。

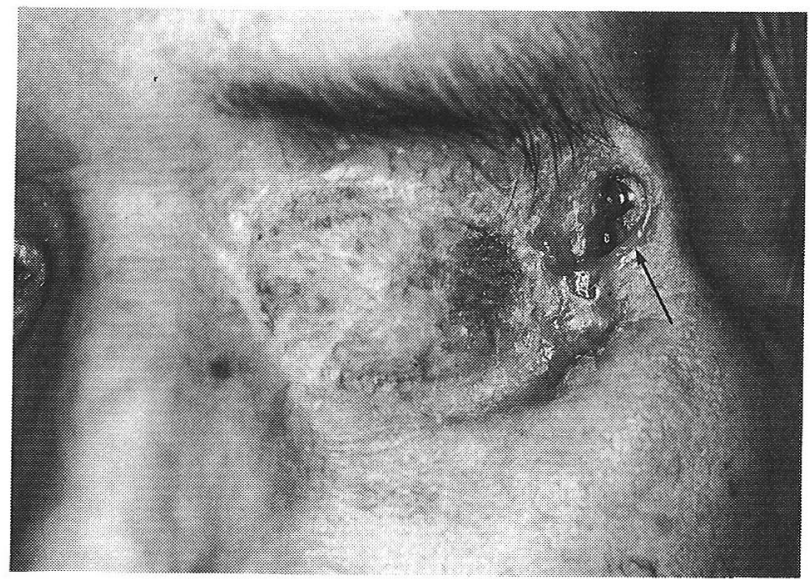

図 8 術後 6 ケ月の状態。矢印は義眼のためのインプラント。

様に制酸剤でコントロールできたものと考えている。胃 漿膜筋層を口腔内に利用し粘膜の再生を促寸方法も考え られるが, 版痕治癒する可能性もあり, やはり粘膜の欠 損部には粘膜がよいと考え, 症例を選べば, やはり全層 で用いることが良いと考えている。

近年内視鏡外科の発展により，われわれも内視鏡下? にあるいは内視鏡補助下の最小開腹術（minimum laparotomy）にて胃壁付き大網を採取しているため， 術後の腹部疼痛は少なく，早期離床が望める。

胃壁付き大網弁は, 大網の有する血管茎が長いという 利点の他に粘膜の再建や, water-tight や air-tight を 得ることができ，さらに bridge flap としての利用も できるため有用であると思われた。 


\section{まとめ}

頭頸部再建に胃壁付き大網弁を利用した。本術式は症 例を選べば有用な再建法であると思われた。（本稿は第 23 回日本頭頸部腫崵学会にて発表した。)

\section{文献}

1) McLean DH. Buncke HJ. Jr. : Autotransplant of omentum to a large scalp defect with microsurgical revascularization. Plast Reconstr Surg 49 : 268-274, 1972.

2) Harii K. Ohmori S. : Use of the gastroepiploic vessels as recipient or donor vessels in the free transfer of composite flap by microvascular anastomosis. Plast Reconstr Surg 52:541-548, 1973.
3) Parachristou D. Fortner JG. : Experimental use of a gastric flap on an omental pedicle to close defects in the trachea, pharynx or cervical esophagus. Plast Reconstr Surg 59:382-385, 1977.

4) Baudet J. : Reconstruction of the pharyngeal wall by free transfer of the greater omentum and stomach. Int $\mathrm{J}$ Microsurg 1:53-59, 1979.

5) Kamei Y. Torii S. : A new composite gastric seromuscular and omental pedicle flap. Ann Surg 220 : 97-101, 1994.

6) Kamei Y. Aoyama H. et al: Composite gastric seromuscular and omental pedicle flap for urethral and scrotal reconstruction after Fournier's gangrene. Ann Plast Surg 33: 565-568, 1994.

7) Kamei Y. Torii S. et al: Endoscopic omental harvest. Plast Reconstr Surg 102 : 2450-2453, 1998. 


\title{
RECONSTRUCTION OF HEAD AND NECK USING THE COMPOSITE STOMACH-OMENTAL FLAP
}

\author{
Yuzuru KAMEI, Shuhei TORII, Takashi HASEGAWA, \\ Yoshihiro HOTTA and Osamu NISHIZEKI \\ Department Plastic and Reconstructive Surgery, \\ Nagoya University School of Medicine
}

The omental flap is useful for reconstructive surgery. It is used extensively to cover difficult, infected wounds or complex cavities. A composite stomach-omental flap was used for reconstruction of head and neck.

The composite full-thickness gastric wall and omental flap was used in 2 cases. One was reconstruction of the buccal mucosa, and the other was reconstruction of the oral base. In the case of reconstruction of the oral base, the flap was used as a bridge flap, that is, the distal end of the right gastroepiploic vessels was anastomosed to the vessels of the free fibula flap.

The composite gastric seromuscular patch and omental flap was used in 2 cases. One was a case of cerebrospinal fluid leakage, and the other was that of defect of the orbit.

The composite stomach-omental flap is useful for the reconstruction of head and neck not only because it has a long pedicle of vessels but also because it can provide an immediate airtight or watertight seal. Furthermore, it is useful for the reconstruction of difficult and complex defects because it can be used as a bridge flap. 